DOI: https://doi.org/10.32839/2304-5809/2021-4-92-48

УДК 81'276:811.111'25:791

Шийка Ю.І., Мацько А.Б.

Національний університет «Львівська політехніка»

\title{
ОСОБЛИВОСТІ ПЕРЕКЛАДУ НАЗВ КІНОФІЛЬМІВ
}

\begin{abstract}
Анотація. Назва фрільму виконуе не лише репрезентативну функцію, а також є метонімічним відображенням всього кінофільму, зміст та особливості якого представлені одним словом або фразою. Тож, назва є одним із факторів, що визначають, чи зацікавиться аудиторія фрільмом чи захоче знайти про нього якусь додаткову інформацію та врешті-решт подивитися його. Можна стверджувати, що назва фрільму нагадуе рекламний слоган продукту і має свої типові риси. Окрім того, назва повинна контекстуально відповідати сюжету, а також бути формально та семантично привабливою. Як правило, заголовок є стислим і зазвичай використовуе різні мовні засоби, такі як ідіоми або гру слів, щоб привернути увагу. Багато назв також оперують натяками чи метафорами, які діють як загадки, які під силу розгадати лише тим, хто переглядає певний фільм. У статті розглянуто категорії назв фрільмів та стратегії їх перекладу. Зроблено аналіз перекладу англомовних назв фільмів українською мовою на основі назв ста кінострічок, представлених на веб-сайті Кіно-театр.uа.
\end{abstract}

Ключові слова: назва кінофільму, аудіовізуальна продукція, локалізація, адаптація, стратегії перекладу .

Shyika Yuliia, Matsko Andrii

Lviv Polytechnic National University

\section{PECULIARITIES OF TRANSLATION OF MOVIE TITLES}

Summary. A film title performs not only a representative function but also is a metonymic reflection of the whole film, the content and features of which are represented by one word or phrase. Therefore, a film title is one of the factors that determine whether the audience is interested in the film, wants to find some additional information about it and eventually watch it. It can be argued that a film title resembles an advertising slogan of a product and has its typical features. Besides, the title should be contextually relevant to the plot, as well as be formally and semantically attractive. Usually, the title is concise and frequently uses various expressions, such as idioms or puns, to draw attention. Many titles also use hints or metaphors that act as riddles that only those who watch a particular movie can solve. In the article, the categories of film titles and strategies for their translation have been considered. An analysis of the translation of English-language film titles into Ukrainian has been made. It has been concluded that a successful translation involves the reproduction of specific features of the source text in the target text to allow the latter to function for the purpose intended by the author of the original text. In the case of film titles, the most important thing is not to preserve the semantic content, but rather to keep an attractive phrase that is easy to remember and represents the plot. Such a translation can be referred to as "commercial" because it is focused on achieving a certain marketing and commercial success of the film. In this case, the translator acts as an intermediary between the source and target texts. Film title domesticators should always take into account the interests of the target audience, its cultural, religious and worldview peculiarities.

Keywords: film title, audiovisual product, localization, adaptation, translation strategies.

$\Pi$ остановка проблеми. Сьогодні кінематограф е однією з найбільш затребуваних сыер ринку послуг. Популярність фрільму часто багато в чому визначається його назвою, адже ефектним заголовком набагато легше зацікавити глядача, ніж описом сюжету. Назва е своерідною запорукою успіху, і їі едрективне сприйняття відразу позначаеться на касових зборах. Переклад назви фрільму - складне та відповідальне завдання. Такий переклад можна назвати "комерційним», адже він оріентований на досягнення певного маркетингового, комерційного успіху філььму. При цьому перекладач повинен виступати як посередник між текстами мовою оригіналу і мовою перекладу. Адаптація назви художнього твору або кінофрільму завжди повинна брати до уваги специфріку цільової аудиторії, їі культуру, релігію та світогляд загалом.

Аналіз останніх досліджень і публікацій. Питання перекладу назв кінофільмів, його особливостей та проблем стало об'єктом дослідження як вітчизняних, так і зарубіжних науковці. Серед них можна виокремити наукові праці Е. Балоу, Л. Богуцького, О. Капустіної, П. Ланга, К. Сіннер, Т. Яхнюк та інших.
Виділення не вирішених раніше частин загальної проблеми. Актуальність дослідження зумовлена існуючими неточностями у перекладі назв кінострічок, яких в майбутньому вдасться уникнути, взявши до уваги попередній досвід перекладу.

Мета статті. Головною метою статті е розглянути основні категорії назв кінострічок та шляхом аналізу виявити найбільш поширені стратегії перекладу, проаналізувати переклад назв англомовних фільмів українською мовою.

Виклад основного матеріалу. Одне з найактуальніших питань перекладу аудіовізуальної продукції - це переклад назв фільмів. 3 одного боку, локалізація продуктів різниться від ринку до ринку. Основною причиною перекладу назви кінопродукту є те, що, по-перше, цільова аудиторія краще розуміє про що йтиметься у фільмі, а по-друге, локалізатори, чи то пак, перекладачі, візьмуть до уваги місцеву специфіку у сфері ідеології, релігії, гендеру чи культури. 3 іншого боку, переклад назв простіший у менш канонічних жанрах. Оригінальні назви фільмів та сучасні назви серіалів зберігаються частіше, ніж у ми- 
нулому. Назви мультрільмів, як правило, перекладаються, іноді цілком вільно. Документальні фільми зазвичай перекладають буквально. Зрештою, аудіовізуальний режим також впливає на вибір. Фільми із субтитрами частіше зберігають свої оригінальні назви, тоді як дубляж надае перевагу перекладеним назвам [2].

У більшості випадків назви фрільмів не можна перекласти буквально. Часто це трапляється через культурні відмінності, каламбури чи ідіоми, які не мають відповідників у цільовій мові. Хоча 3 іншого боку, якщо назву перекладають дослівно, може виникнути ще більше непорозумінь, і потенційна аудиторія може скласти хибне враження про кінопродукт. Як приклад можна навести кінострічку «One Flew over the Cuckoo 's Nest» режисера Кена Кізі. Назва майже буквально перекладена українською «Пролітаючи над гніздом зозулі». Загалом, можна стверджувати, що це хибний переклад, адже слово «Cuckoo» в англійській мові позначає не лише гніздового перелітного птаха, але й використовуеться як синонім до слова «божевільний», «ненормальний». Виходячи із сюжету фільму, можна стверджувати, що «Cuckoo's Nest», тобто «гніздо зозулі» позначає психіатричну лікарню. Однак, некоректний переклад радше неприємний виняток, аніж тенденція. Серед численних кінофрільмів 3 «непростими» назвами зустрічаємо цікаві переклади, як от «Some Like it Hot» (досл. Дехто любить гаряче) - «У джазі тільки дівчата»; «Woman of Affairs» (у цьому випадку слово «Affairs» можна хибно інтерпретувати як "роман», «любовна історія») - «Жінка справи» [1; 8].

Загалом назви фільмів відіграють роль посередника між виробником та споживачем, адже назва ідентифікуе фрільм. Означення фрільму необхідне на всіх етапах виробництва кінопродукту, починаючи від першого рядка сценарію і закінчуючи рецензією в журналі або на інтернет-порталі. Назва допомагає зрозуміти нескінченний потік трейлерів, статей, новин та імен, допомагає структурувати терабайти інформації про фрільм та все, що з ним пов'язане [3].

Якщо назва фрільму написана рідною мовою глядачів, усі ці фрункцї реалізовуються без особливих проблем. Але коли фільм беруть у прокат закордоном, його необхідно перекласти мовою цільової аудиторії. Разом 3 тим слід зазначити, якщо переклад неякісний, вищезазначені фрункції не будуть реалізовані або будуть реалізовані лише частково. Причиною можуть стати труднощі, 3 якими стикається перекладач під час перекладу назв фрільмів. Працюючи над назвою фрільму, перекладач створюе кілька синонімічних варіантів назви кінострічки, які зазвичай відрізняються лише смисловими акцентами та благозвучністю [3; 10]. Також доволі часто складність перекладу полягає в підборі досить короткого аналогу оригінального заголовка, зберігаючи стилістичну єдність, і наближеності смислового змісту перекладу та оригіналу. Саме на цьому моменті часто виникають помилки, оскільки інколи з різних причин назви фрільмів вимагають подальшого розширення та пояснення, однак перекладач не може вийти за рамки кількох слів. Наприклад, "The Assassination of Richard Nixon" - "Вбити президента. Замах на Річарда Ніксона”. Назви фрільмів, які складаються
3 двох-трьох речень, ніхто ніколи не запам'ятає, ними буде незручно користуватися [6].

Загалом компанії-дистриб'ютори розглядають орільм як продукт чи товар, тому кіновиробники прагнуть зробити його справжнім хітом. Одним із способів досягти цього - це яскрава, пікава та інтригуюча назва, яку легко запам'ятати, як от "Music and Lyrics” - “Зник з очей, то геть із чарту”, замість дослівного "Музика та слова". Саме такі назви кінострічок приваблюють велику аудиторію: "Employee of the Month" - "Побачення моєї мрії". Разом 3 тим не варто забувати про точність перекладу, який не порушуватиме стилістичної гармонії назви, однак зробить її привабливою для глядачів. Однак, у деяких випадках реалії мови оригіналу, тобто нееквівалентну лексику, якої немає в мові тієї чи іншої цільової аудиторії, можна зустріти у назвах кінофрільмів, як от “Trainspotting” (хобі, що полягає у спостереженні за поїздами та записом їхніх номерів) - "На голщі". У таких випадках перекладач намагається виразити реалію такими мовними засобами, щоб зробити ії зрозумілою потенщійним глядачам та прийнятною з точки зору їхньої культури. Інколи неточна інтерпретація реалії може призвести до помилки у назві кінострічки, а відтак i до хибного сприйняття кінопродукту [5].

Переклад назви фрільму починається 3 аналізу загального сюжету та його розкриття у назві фрільму. Тільки у такий спосіб можна вирішити, яку стратегію застосовувати для коректної інтерпретації назви. Загалом, назву кінострічки можна адаптувати до будь-якого конкретного жанру, як от “Thursday" "Кривавий четвер", "Ouija" - "Віджа. Смертельна гра", "Eliza Graves” - "Будинок проклятих" [4].

У нашому дослідженні було проаналізовано 300 англійських назв кінострічок та їх еквіваленти українською мовою. Розглядалися фрільми таких жанрів, як комедія (100 фрільмів), жахи (100 фільмів), бойовики (100 фільмів), які були відібрані з веб-сайту Кіно-театр.uа. Усі назви фрільмів були категоризовані за трьома критеріями:

1) структура назв;

2) стилістичні особливості;

3) метод перекладу.

У дослідженні спершу було досліджено структури заголовків. Було виявлено, що усі назви кінострічок поділяються на 4 типи, а саме:

1. Однокомпонентна структура: "The Equalizer", "RoboCop", "Transcendence", "Everly", "Ouija", "Stretch", "The Signal", "Gotham", "Jessabelle”, "Salem", "The Strain";

2. Двокомпонентна структура: "The Maze Runner", "Gone Girl”, "John Wick", "The November Man", "Into the Storm", "The Imitation Game", "Left Behind", "Eliza Graves"

3. Структура словосполучення: "Sin City: A Dame to Kill For", "Jack Ryan: Shadow Recruit", "Night at the Museum: Secret of the Tomb", "Teenage Mutant Ninja Turtles", "Planes: Fire \& Rescue", "Life After Beth", "Postman Pat: The Movie"

4. Структура складової речення: "She's Funny That Way", "This Is Where I Leave You”, "We'll Never Have Paris", "How to Make Love Like an Englishman", "A Million Ways to Die in the West", "Where the Devil Hides", "How to Get Away with Murder", "It Comes at Night"

Схематичний розподіл назв досліджуваних кінострічок представлено на рисунку 1. 


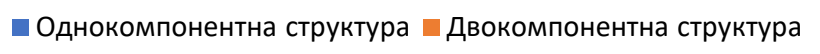

— Структура словосполучення Структура складової речення

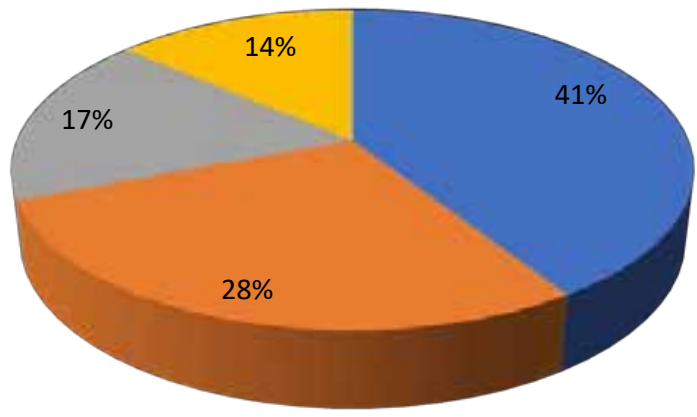

Рис. 1. Структурний розподіл назв кінострічок

Джерело: розроблено авторами

Проаналізувавши способи перекладу, локалізовані назви кінострічок було поділено на 6 груп, a came:

1. Описовий переклад, який передає значення лексичної одиниці у формі фрази. Такий тип перекладу застосовуеться до фрразеологічних одинищь, термінів, нееквівалентної лексики (реалій) та неологізмів: "Ted” - “Третій зайвий”, "LOL" - “Літо . Однокласники. Кохання", "As Above, So Below" "Париж. Місто мертвих", "Unfriended" - "Видалити 3 друзів", "Beyond The Reach" - "Гра на проживання", "Stretch" - “Драйвер на ніч", "Lost River" - “Як упіймати монстра", "Non-Stop" - "Повітряний маршал" "Ride Along" - "Шалений патруль".

2. Дослівний переклад - спосіб передачі денотативного значення лексичної одинищі мовиджерела без збереження звукової чи орфографічної форми, але із відтворенням ії структурної моделі: "Voice from the Stone" - "Голос з каменю", "Atomic Blonde" - "Атомна блондинка", "13 Reasons Why" "13 причин чомy", "The Girl on the Train" - “Дівчина у потягу”.
3. Транскодування - переклад шляхом відтворення звукової графрічної форми мови-джерела за допомогою цільової мови: "Frank” - “Френк”, “Rio 2" "Pio 2", "Annie" - "Eннї", "Gothem" - "Готем".

4. Трансформація, тобто зміна структурної форми мовних одинищь 3 метою досягнення автентичності в перекладі: "This is 40" - "Кохання подорослому", "Ouija” - "Віджа: Смертельна гра", "Sin City: A Dame to Kill For" - "Мiсто гріхів 2: Жінка, заради якої варто вбивати", "California Scheming" "Відв'язна Каліфорнія", "The Purge: Anarchy" "Судна ніч 2", "Where the Devil Hides" - "Рука Диявола", "Through Chemistry" - "Хімія кохання".

5. Жанровий переклад - один із найбільш поширених видів перекладу назви кінострічки, який співвідносить назву із конкретним жанром: "Ouija" "Віджа. Смертельна гра", "Gone Girl" - "Загублена", "Left Behind" - “Залишені”, "Unfriended” - "Видалити 3 друзів", "A Most Wanted Man" - "Наднебезпечний", “Jack Ryan: Shadow Recruit" - “Джек Раян: Теорія хаосу", "Lost River" - "Як упіймати монстра", "Non-Stop" - “Повітряний маршал".

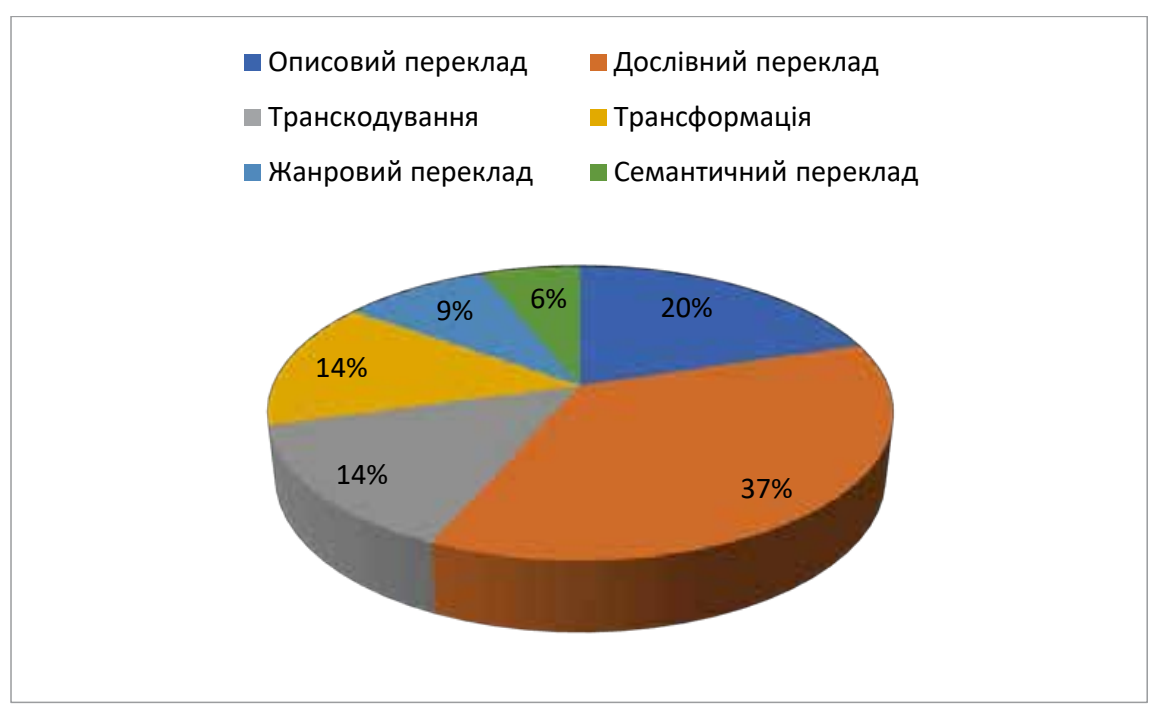

Рис. 2. Способи перекладу назв кінострічок 
6. Семантичний переклад, який за допомогою зміни або додавання лексичних елементів та введення ключових слів фрільму розширюе семантичне поле назви: “The Maze Runner" - "Той, що біжить лабіринтом", "Sin City: A Dame to Kill" - "Мicто гріхів 2: Жінка, заради якої варто вбивати”.

Результати аналізу способів перекладу назв кінострічок представлено на рисунку 2.

Без сумніву назва фрільму тісно пов'язана із сюжетом. Загалом, назва повинна визначати головну тему кінопродукту, яка стає орієнтиром усього, що відбувається на екрані. Однак, в деяких випадках значення назви вислизає від глядача навіть після перегляду кінофрільму. Переважно така ситуація виникає при некоректному перекладі. Беручи до уваги потенційне зацікавлення кінострічкою міжнародною аудиторією, автори сценаріїв зазвичай намагаються не використовувати дражливих елементів, щоб уникну- ти можливих непорозумінь у площині міжкультурної комунікації [7].

Висновки і пропозиції. Отже, успішний переклад передбачає відтворення в тексті цільової мови тих особливостей тексту мови-джерела, які дозволяють останньому фрункціонувати 3 метою, передбаченою автором оригінального тексту. У випадку з назвами фрільмів не завжди найбільш значущим є дотримання індрормативної цінності, тобто семантичного змісту. Слід визнати, що найбільш важливим є збереження привабливої фрорми, яка легко запам'ятовується, а також відповідність назви сюжету фрільму. Часто перекладачі стикаються 3 лінгвістичними обмеженнями, що вимагае значного ступеня творчості з їхнього боку. Зусилля перекладачів дуже часто оцінюються не лише на основі перекладу цільовою мовою. Це результат міжкультурного обміну та потоку інфрормації з-за кордону до певної країни (наприклад, України).

\section{Список літератури:}

1. Bogucki L. Perspectives on Audiovisual Translation / L. Bogucki // Peter Lang, 2010. - 206 p.

2. Bravo J.M. A New Spectrum of Translation Studies / J.M. Bravo, W.J. Hutchins // Universidad De Valladolid, 2004. - 392 p.

3. Cintas J.D. New Trends in Audiovisual Translation / J.D. Cintas // Multilingual Matters, 2009. - 216 p.

4. Faiq S. Discourse in Translation / S. Faiq // Routledge, 2018. - 242 p.

5. Gottlieb H. Multidimensional Translation: Semantics turned Semiotics / H. Gottlieb // Copenhagen: MuTra, 2005. - P. 13-15.

6. Lee T.-K. Applied Translation Studies / T.-K. Lee // Macmillan International Higher Education, 2017. - 178 p.

7. Pinto S.R. Audiovisual Translation: Theoretical and methodological challenges / S.R. Pinto // John Benjamins Publishing Company, 2018. - 146 p.

8. Raw L. Translation, Adaptation and Transformation / L. Raw // A\&C Black, 2012. - 240 p.

9. Sanderson J.D. Focusing on Audiovisual Translation Research / J.D. Sanderson, C. Botella-Tejera // Universitat de València, 2019. - $240 \mathrm{p}$.

10. Sinner C. Translation in the Digital Age: Translation 4.0 / C. Sinner // Cambridge Scholars Publishing, 2020. - 257 p.

\section{References:}

1. Bogucki L. (2010) Perspectives on Audiovisual Translation. Peter Lang, $206 \mathrm{p}$.

2. Bravo J.M., W.J. Hutchins (2004) A New Spectrum of Translation Studies. Michigan: Universidad De Valladolid, 392 p.

3. Cintas J.D. (2009) New Trends in Audiovisual Translation. Multilingual Matters, 216 p.

4. Faiq S. (2018) Discourse in Translation. Routledge, $242 \mathrm{p.}$

5. Gottlieb H. (2005) Multidimensional Translation: Semantics turned Semiotics. Copenhagen: MuTra, pp. 13-15.

6. Lee T.-K. (2017) Applied Translation Studies. Macmillan International Higher Education, 178 p.

7. Pinto S.R. (2018) Audiovisual Translation: Theoretical and methodological challenges. John Benjamins Publishing Company, 146 p.

8. Raw L. (2012) Translation, Adaptation and Transformation. A\&C Black, $240 \mathrm{p}$.

9. Sanderson J.D., Botella-Tejera C. (2019) Focusing on Audiovisual Translation Research. Universitat de València, 240 p.

10. Sinner C. (2020) Translation in the Digital Age: Translation 4.0. Cambridge Scholars Publishing, 257 p. 